\title{
Correction to: Anteromedial positioning of the femoral tunnel in Anterior Cruciate Ligament reconstruction is the best option to avoid revision: a single surgeon registry
}

Ricardo de Paula Leite Cury, Artur Mistieri Simabukuro, Victor de Marques Oliveira, Diego Escudeiro* (D),

Pedro Baches Jorge, Fabrício Roberto Severino and Luiz Gabriel Betoni Guglielmetti

\section{Correction to: J Exp Orthop 7:11 (2020)}

\section{https://doi.org/10.1186/s40634-020-00225-x}

Following publication of the original article, the authors opted to correct the middle name of author Ricardo de Paula Leite Cury from Paulo to Paula.

The original article [1] has been updated.

Published online: 16 May 2020

\section{Reference}

1. de Paula Leite Cury R, Simabukuro AM, de Marques Oliveira V et al. Anteromedial positioning of the femoral tunnel in anterior cruciate ligament reconstruction is the best option to avoid revision: a single surgeon registry. J Exp Ortop https://doi.org/10.1186/s40634-020-00225-x

\footnotetext{
The original article can be found online at https://doi.org/10.1186/s40634020-00225-x.

* Correspondence: diegoescudeiro@gmail.com

The original article can be found online at https://doi.org/10.1186/s40634020-00225-x

Orthopedics and Traumatology Department, Faculdade de Ciências Médicas da Santa Casa de Misericórdia de São Paulo, R. Dr. Cesário Mota Júnior, 61 Vila Buarque, São Paulo 01221-020, Brazil
}



(๑) The Author(s). 2020 Open Access This article is licensed under a Creative Commons Attribution 4.0 International License, which permits use, sharing, adaptation, distribution and reproduction in any medium or format, as long as you give appropriate credit to the original author(s) and the source, provide a link to the Creative Commons licence, and indicate if changes were made. The images or other third party material in this article are included in the article's Creative Commons licence, unless indicated otherwise in a credit line to the material. If material is not included in the article's Creative Commons licence and your intended use is not permitted by statutory regulation or exceeds the permitted use, you will need to obtain permission directly from the copyright holder. To view a copy of this licence, visit http://creativecommons.org/licenses/by/4.0/. 